\title{
Synthesis and Characterization of Coordination Polymers Constructed from $\left[\mathrm{Zn}^{\mathrm{II}}, \mathrm{Cd}^{\mathrm{II}}\right]-2,2$ '-dipyridine and Biphenyl-4, 4'-Dicarboxylic Acid
}

\author{
Pramod Kumar Yadav ${ }^{*}$ \\ Dept. of Chemistry, Tribhuvan University, T.R.M. Campus, Birgunj 44301, Nepal \\ Email: pramod_yadav1155@yahoo.com
}

\begin{abstract}
The coordination polymers $\left[\mathrm{Zn}\left(4,4^{\prime}-\mathrm{BDA}\right)(\mathrm{bpy})\right]_{n}$ (1) and $\left[\mathrm{Cd}\left(4,4^{\prime}-\mathrm{BDA}\right)(\mathrm{bpy})\left(\mathrm{H}_{2} \mathrm{O}\right)_{2}\right]_{n}$ (2) have been synthesized from biphenyl-4,4'-dicarboxylic acid $\left(\mathrm{H}_{2} \mathrm{BDA}\right)$ with the help of $\left[\mathrm{Zn}^{I I}, C \mathrm{C}^{I I}\right]-2,2^{2}$-bipyridine. The complexes 1 and $\mathbf{2}$ formed from the same ligand $\left(\mathrm{H}_{2} \mathrm{BDA}\right)$ have different molecular structures. It reveals the fact that organic linkers display different coordination preferences at different metal ions.
\end{abstract}

Key words: Biphenyl-4, 4'-dicarboxylic acid, MOFs, 2, 2'-bipyridine, solvothermal reaction, $N, N$ 'dimethylformamide

\section{Introduction}

Metal-organic frameworks (MOFs) or coordination polymers form a new class of porous materials consisting of inorganic building units joined by organic links ${ }^{1}$. MOFs are receiving growing attention because of their intriguing topologies and diverse functionality ${ }^{2}$. In the construction of many interesting systems, polycarboxylate aromatic ligands have been successfully employed as carboxylic groups can be partially or completely deprotonated and can coordinate with metal ions in multicoordinated ways ${ }^{3}$. Carboxylates are attractive metal binding units in coordination networks due to the negative charge that significantly enhances their ability to bind strongly to metal centers. The ligands containing multiple carboxylic acid units have been found to be good candidates because they act not only as hydrogen acceptors but also as hydrogen donors, depending on the number of deprotonated carboxylic groups ${ }^{4}$.

The auxiliary ligands like 2, 2'-bipyridine play an important role in the formation of the final structure of the complex as it impact on the conformations of the flexible carboxylic ligand (trans- or cis-). Lowdimension structures can be extended into high-dimensional supramolecular networks by terminal ligand like 2, 2'-bpy through weak interactions ${ }^{5}$.

Due to wider range of coordination numbers together with their applications in luminescence and biological activities ${ }^{6,7}$, the metal $(\mathrm{Zn}, \mathrm{Cd})$ ions with $\mathrm{d}^{10}$ configuration are highly promising. Thus, the present article is important as it deals with the synthesis and characterization of the structures obtained on the skeleton of $\mathrm{d}^{10}$ divalent metal $\left(\mathrm{Zn}^{\mathrm{II}}, \mathrm{Cd}^{\mathrm{II}}\right)$ 2,2'-bipyridines together with biphenyl -4, 4'-dicarboxylic acid.

\footnotetext{
* Corresponding author
} 


\section{Experimental Methods}

All reagents and solvents were commercially available and used as received. The carbon, nitrogen, and hydrogen contents of the solid complexes were determined by Carbo-Erba elemental analyzer 1108 . The infrared spectra of the complexes were recorded on a Varian 3100 FT-IR spectrometer (4000-400 cm-1) using $\mathrm{KBr}$ disks. $\mathrm{M}(\mathrm{bpy})\left(\mathrm{NO}_{3}\right)_{2} \cdot \mathrm{H}_{2} \mathrm{O}$ [M $\left.=\mathrm{Zn}(\mathrm{II}) / \mathrm{Cd}(\mathrm{II})\right]$ were prepared using the procedure as reported by Sen et al. ${ }^{8}$ for analogous complexes.

The complexes were synthesized by solvothermal reaction ${ }^{9}$. In a typical synthetic procedure, $\mathrm{Zn}(\mathrm{bpy})\left(\mathrm{NO}_{3}\right)_{2} \cdot \mathrm{H}_{2} \mathrm{O}(0.381 \mathrm{~g}, 1.0 \mathrm{mmol})$ and $\mathrm{Cd}(\mathrm{bpy})\left(\mathrm{NO}_{3}\right)_{2} \cdot \mathrm{H}_{2} \mathrm{O}(0.428 \mathrm{~g}, 1.0 \mathrm{mmol})$ were added to the solution of biphenyl-4,4'-dicarboxylic acid $(0.121 \mathrm{~g}, 0.5 \mathrm{mmol})$ in $\mathrm{N}, \mathrm{N}^{\prime}$-dimethylformamide $(5.0 \mathrm{~mL})$. When the corresponding mixtures were heated at $135-145^{\circ} \mathrm{C}$ for $3-5 \mathrm{~h}$, the complexes were isolated in $65-75 \%$ yield. They were found insoluble in common organic solvents and were melting above $200{ }^{\circ} \mathrm{C}$.

Scheme 1. Synthetic strategy for complexes.

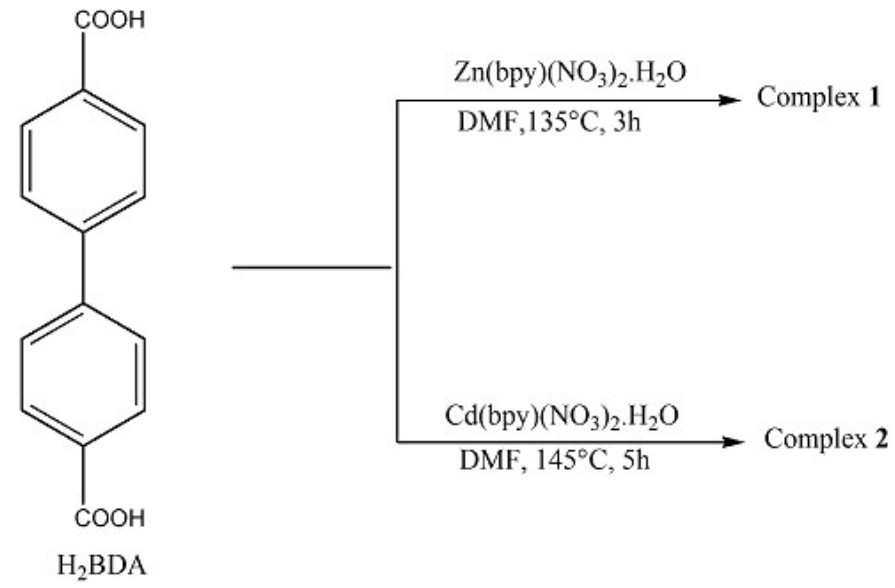

\section{Results and Discussion}

Table 1. Mol. formula, M.P., \%yield, elemental analyses and IR data of 1 \& 2

\begin{tabular}{|c|c|c|c|c|}
\hline $\begin{array}{l}\text { Molecular formula } \\
\text { of complexes }\end{array}$ & M.P. $\left({ }^{\circ} \mathrm{C}\right)$ & $\%$ Yield & $\begin{array}{l}\text { Elemental analyses } \\
(\%) \\
\quad \text { Calculated } \\
\quad \text { (Found) }\end{array}$ & $\begin{array}{l}\text { Major IR peaks } \\
\qquad\left(\mathrm{v} \mathrm{cm}^{-1}\right)\end{array}$ \\
\hline & & & $\begin{array}{lll}\text { C } & \text { H } & \text { N }\end{array}$ & \\
\hline $\mathrm{C}_{24} \mathrm{H}_{16} \mathrm{~N}_{2} \mathrm{O}_{4} \mathrm{Zn}(\mathbf{1})$ & $>200$ & 60 & $\begin{array}{ccc}62.47 & 3.47 & 6.07 \\
(60.45)(3.30) & (5.95)\end{array}$ & $\begin{array}{l}3059(\mathrm{~m}), 1679(\mathrm{~s}), \\
1604(\mathrm{~s}), 1545(\mathrm{~s}), 1420(\mathrm{~s}), \\
1385(\mathrm{vs}), 1220(\mathrm{~m}), \\
1100(\mathrm{~m}), \\
1005(\mathrm{~m}), 855(\mathrm{~s}), 790(\mathrm{~s}),\end{array}$ \\
\hline
\end{tabular}




\begin{tabular}{|c|c|c|c|c|}
\hline & & & & $725(\mathrm{~s}), 640(\mathrm{~m}), 420(\mathrm{~m})$ \\
\hline $\mathrm{C}_{24} \mathrm{H}_{20} \mathrm{~N}_{2} \mathrm{O}_{6} \mathrm{Cd}(\mathbf{2})$ & $>200$ & 70 & $\begin{array}{ccc}52.92 & 3.67 & 5.14 \\
(51.28) & (3.15) & (5.11)\end{array}$ & $\begin{array}{l}3068(\mathrm{~m}), 1599(\mathrm{~s}), \\
1550(\mathrm{~s}), 1425(\mathrm{~s}), 1388(\mathrm{vs}), \\
1230(\mathrm{~m}), 1090(\mathrm{~m}), 870(\mathrm{~s}), \\
790(\mathrm{~s}), 720(\mathrm{~s}), 645(\mathrm{~m}), \\
475(\mathrm{~m})\end{array}$ \\
\hline
\end{tabular}

In infrared spectra of the complexes, the characteristic band of carboxylic acid group observed at $1681 \mathrm{~cm}^{-1}$ in the spectrum of free ligand 4,4'- $\mathrm{H}_{2} \mathrm{BDA}$, was absent in the spectra of its complexes. It supported that deprotonated ligands had coordinated with metal ions in the complexes $\mathbf{1}$ and $\mathbf{2}^{10}$. The peaks observed at 1679 and $1599 \mathrm{~cm}^{-1}$ in the spectra of complexes $\mathbf{1}$ and $\mathbf{2}$ were assigned to $v_{\text {asym }}$ $\left(-\mathrm{COO}^{-}\right)$vibration, whereas $v_{\text {sym }}\left(-\mathrm{COO}^{-}\right)$vibration was observed at 1604 and $1388 \mathrm{~cm}^{-1}$, respectively. Thus, peak separations between $v_{\text {asym }}\left(-\mathrm{COO}^{-}\right)$and $v_{\text {sym }}\left(-\mathrm{COO}^{-}\right)$were found as 75 and $211 \mathrm{~cm}^{-1}$, which supported bis-bidentate and monodentate coordination modes of carboxylate groups, respectively. The spectra of the same complexes showed a peak at $1420 \mathrm{~cm}^{-1}$ assigned to the $v(\mathrm{~N}=\mathrm{N})$ vibration ${ }^{11}$. The bands observed at 500-480 and 420-380 $\mathrm{cm}^{-1}$ were assigned to $v(\mathrm{M}-\mathrm{N})$ and $v(\mathrm{M}-\mathrm{O})$ vibrations, respectively ${ }^{12}$.The above experimental results suggest the following structures for the two complexes:

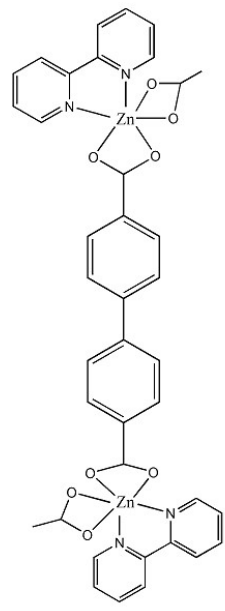

1

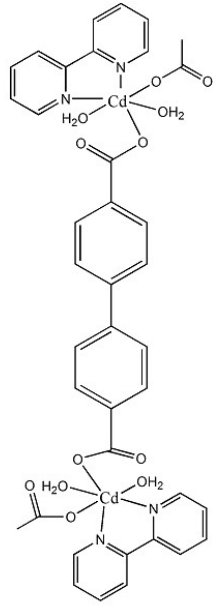

2

Figure 1: Possible structures for complexes $1 \& 2$

\section{Conclusions}

Two new coordination polymers were obtained by reaction of metal nitrate containing 2, 2'-bipyridine $\left[\right.$ metal $\left.=\mathrm{Zn}^{\mathrm{II}}, \mathrm{Cd}^{\mathrm{II}}\right]$ separately with biphenyl-4, 4'-dicarboxylic acid. Elemental analyses and IR spectroscopy techniques have been used for characterization of the complexes. They could be promising 
candidates as adsorbents for gas separation since such types of metal-organic frameworks show the formation of porous structures ${ }^{13}$.

\section{Acknowledgement}

The author is thankful to the Head, Department of chemistry, BHU, Varanasi, India for providing characterization facilities. Thanks are also due to the members of dept. of chemistry, Tribhuvan University,T.R.M. Campus, Birgunj for his valuable suggestions and encouragement.

\section{References}

1. O. M. Yaghi, M. O'Keeffe, N. W. Ockwig, H. K. Chae, M. Eddaoudi and J. Kim, Nature, 2003,423, 705-714.

2. G. Ferey and C. Serre, Chem. Soc. Rev., 2009, 38, 1380-1399.

3. D. J. Tranchemontagne, J. L. Mendoza-Cortes, M. O'Keeffe and O. M. Yaghi, Chem. Soc. Rev., 2009, 38, 1257-1283.

4. X.-L. Wang, C. Qin, and E.-B. Wang, Cryst. Growth Des., 2006, 6,439.

5. D. K. Kumar, A. Das and P. Dastidar, Cryst. Growth Des., 2006, 6, 1903-1909.

6. K. J. Wei, Y. S. Xie, J. Ni, M. Zhang and Q. L. Liu, Cryst. Growth Des.,2006 6, 1341-1350.

7. G. Parkin, Chem. Rev., 2004,104,699-767.

8. S. S. Mitra, P. Kundu, M. K. Saha, C. Kruga and J. Bruckmann, Polyhedron, 1997, 6, 24752481.

9. X. Guo, G., Li, Z. Zhu, F. Sun, Z. Yang and S. Qiu, Chem.Commun, 2006,. 30, 3172-3174.

10. L. J. Bellamy, The Infrared Spectra of Complex Molecules. Wiley: New York, 1958.

11. Z.-F. Chen, Z.-L. Zhang, Y.-H. Tan, Y.-Z. Tang, H.-K. Fun, Z.-Y. Zhou, B. F. Abrahams and H. Liang., CrystEngComm, 2008, 10, 217-231.

12. K. Nakamoto, Infrared and Raman Spectra of Inorganic and Coordination Compounds. John Wiley \& Sons: New York, 1997.

13. S. Kitagawa, R. Kitaura and S. Noro, Functional Porous Coordination Polymers, Angew. Chem. Int. Ed., 2004, 43, 2334-2375. 